\title{
Recenzje
}

DOI: $10.14746 /$ por.2018.2.22

\section{ROMANTYZM I POSTKOLONIALIZM W EUROPIE ŚRODKOWOWSCHODNIEJ}

\author{
MACIEJ JUNKIERT ${ }^{1}$
}

Kuziak Michał, Nawrocki Barłłomiej, red. Romantyzm środkowoeuropejski w kontekście postkolonialnym. Cz. 1. Warszawa: Wydawnictwo IBL PAN, 2017. 743 S.

Książka przygotowana i zredagowana przez Michała Kuziaka i Bartłomieja Nawrockiego jest dziełem ważnym, oczekiwanym i potrzebnym. W ciągu ostatnich lat odnotowujemy znaczący wzrost zainteresowania tematyką postkolonialną, niestety nie tylko wśród naukowców. Do języka współczesnej publicystyki oraz wypowiedzi niektórych polityków przeniknęły, przeważnie wyrwane z kontekstu, elementy rozważań związanych z kolonializmem. Tym większe znaczenie książki, która nadinterpretacjom i nadużyciom przeciwstawia rzetelną refleksję naukową, będącą efektem kilkuletnich prac dużego interdyscyplinarnego zespołu badawczego pracującego w ramach grantu Narodowego Programu Rozwoju Humanistyki.

Tematyka postkolonialna, pojawiająca się sukcesywnie w licznych publikacjach $\mathrm{z}$ ostatnich lat, nie odzwierciedlała do tej pory problemu romantyzmu jako epoki z wielu względów kluczowej do zrozumienia środkowoeuropejskiego dziedzictwa. Kuziak pisze:

Romantyzm, a w zasadzie romantyzmy środkowoeuropejskie, pozostają ciągle istotnym punktem odniesienia dla współczesnych kodów tożsamościowych, pomimo pojawiających się tu i ówdzie pogłosek o zmierzchu paradygmatu romantycznego. Po pierwsze, dlatego że to właśnie $\mathrm{w}$ romantyzmie kształtują się podstawowe narracje określające wspólnotową tożsamość narodów środkowoeuropejskich, ich sposób rozumienia siebie i świata - co znamienne, w kontekście doświadczenia upodrzędnienia i obcej hegemonii. Po drugie zaś, o czym już wspominałem, kwestie te zresztą splatają się, Europa Środkowa styka się w romantyzmie ze zjawiskiem modernizacji, sytuując się na jej peryferiach,

1 E-mail: mjunkiert@gmail.com 
poddanych logice pragnienia nowoczesności i krytycznego dystansu wobec niej, wytwarzając narracje związane z takim, trwającym do dzisiaj, spozycjonowaniem się (Kuziak, Nawrocki 19).

Założenia redaktorów monografii wskazują wyraźnie, że romantyzm nie został potraktowany jako jedna z wielu epok. Środkowoeuropejski romantyzm oznacza w tym przypadku narodziny nowoczesności, a wraz z nią określonego paradygmatu konstruowania przynależności do wspólnoty narodowej i sposobów podtrzymywania tej więzi. Chodzi o narodziny opóźnione pod względem szybszego ukonstytuowania się „wyobrażonych wspólnot” Brytyjczyków lub Francuzów, ale równoczesne na przykład względem Niemców. W duchu badań nad narodzinami nowoczesnych narodów, mimo wielu różnic odwzorowujących propozycje Ernsta Gellnera, Benedicta Andersona i Anthony'ego Smitha, mówimy w tym przypadku o takim rodzaju więzi między ściśle zdefiniowanym gronem ludzi, która skutkuje narodzinami wspólnoty o postfeudalnym i częściowo postreligijnym, zsekularyzowanym charakterze.

Pozwolę sobie zacząć od wyrażenia pewnego niedosytu. A jest to kłopot potrójny, związany ze szkicowym nakreśleniem i opracowaniem niektórych tematów. Problem pierwszy dotyczy relacji między Polakami i innymi narodami w przedrozbiorowej Rzeczpospolitej Obojga Narodów. Czy relacje przedrozbiorowe między Polakami i mieszkańcami Ukrainy miały charakter kolonialny? Zgodnie z wieloletnimi badaniami Jana Kieniewicza relacje te przypadły na tzw. „ekspansje przedkolonialną". Jak pisał Kieniewicz (co pokrywa się z rozważaniami także innych autorytetów, podobnie ocenia tę kwestię chociażby Edward W. Said):

Podboje kolonialne pojawiły się dopiero wtedy, kiedy w Europie istniały już państwa narodowe, a dotychczasowe systemy eksploatacji krajów zamorskich przestały spełniać swoją rolę. Przypada to na drugą połowę XVIII i pierwszą połowę XIX wieku. Było bowiem niezbędne, by realizacja ekspansji i formy utrwalania doprowadziły do wrośnięcia Europejczyków w lokalne systemy pozaeuropejskie. [...] Podbój kolonialny okazał się podstawowym elementem procesu formowania się systemu kolonialnego. Dopiero bowiem instalowanie władzy europejskiej nad społeczeństwem innej cywilizacji dało możliwość powstawania struktur eksploatujących, zdolnych do wspomagania procesu kształtowania się kapitalizmu w metropoliach. Inaczej mówiąc, Europa musiała dorosnąć do możliwości podboju, musiała znaleźć się ponownie w sytuacji koniecznej (Kieniewicz 1986: 88-89).

Książka na wiele różnych sposobów analizuje romantyczne metody konceptualizacji przedrozbiorowego doświadczenia, związanego z polskim panowaniem nad Ukraińcami, Białorusinami i Litwinami. W tej materii przynosi dużo nowych rozpoznań i odczytań, jednak przydałby się choćby jeden głos sytuujący sytuację 
Polski przed 1795 rokiem na tle ewolucji światowego systemu kolonialnego. Faza (ekspansja) przedkolonialna miała swoją własną logikę wynikającą choćby z tego, że system kapitalistyczny stał wówczas na zdecydowanie niższym poziomie, a priorytetem europejskich mocarstw było maksymalizowanie zysków przy minimalnym zaangażowaniu $\mathrm{w}$ istnienie samych kolonii i zarządzanie nimi. A zatem zanim narodził się system kolonialny (w terminologii Kieniewicza), Rzeczpospolita Obojga Narodów utraciła suwerenność.

Książka zyskałaby niewątpliwie na próbie przybliżenia i scharakteryzowania tego fenomenu: czym były polskie Kresy w kulturowej perspektywie porównawczej, zanim narodził się romantyczny fantazmat bezkrwawego zjednoczenia różnych ludów pod polskim berłem? Takich odpowiedzi na pytanie, czym była polska ekspansja na wschód w XVII i XVIII wieku udziela właśnie Kieniewicz, precyzyjnie odróżniając polską i rosyjską aktywność na tych terenach:

Ekspansja Rzeczpospolitej oznaczała objęcie Międzymorza przestrzenią europejskiego pogranicza, to znaczy włączenie w cywilizację europejską. Pogranicze oznaczało zarazem próbę zbudowania własnego projektu cywilizacyjnego. Ukształtowany od wieku XIV w kręgu chrześcijaństwa zachodniego projekt polski oferował ludziom Międzymorza opcję zdecydowanie odmienną od tej postaci cywilizacji, jaką w tym czasie przyjmowała Moskwa. To nie zmienia faktu, że była to propozycja adaptacji. Klęska polskiego projektu w wieku XVII oznaczała otwarcie pogranicza na ekspansję rosyjską (Kieniewicz 2008: 249-250, podkr. J.K.).

Problem drugi związany jest z książką Larry'ego Wolffa. Pojawia się wielokrotnie na kartach omawianego opracowania, ale odnoszę wrażenie, że autorzy niedostatecznie wykorzystali całokształt jego koncepcji. Redaktorzy wspominają o roli Herdera w konstytuowaniu dominującego dyskursu zachodnioeuropejskiego, który wyznaczył Europie Wschodniej miejsce przestrzeni na pograniczu cywilizacji i barbarzyństwa:

O skomplikowaniu podjętego $\mathrm{w}$ książce problemu może świadczyć choćby sama sprawa Słowian. Chodzi o swego rodzaju podmianę tożsamościową, związaną z odkryciem, a w zasadzie skonstruowaniem, tożsamości tego ludu dla Europy przez Herdera. Znamienna jest tak orientalizacja wpisana przez niego w wizję Słowian i Słowiańszczyzny - wbrew deklaracjom myśliciela, który postępowanie Niemców ze Słowianami porównuje do kolonizacji Peru przez Hiszpanów - usprawiedliwiająca ich podbój, jak i fakt, że oni sami podjęli ten dyskurs, wpisując się w ten sposób w relację zależnościową, nazywając przy tym niewielki fragment Myśli o filozofii dziejów „,łłowiańskim rozdziałem” (Kuziak, Nawrocki 16).

Otóż fenomen książki Wolffa polega na tym, że Herder jest w jego przypadku tylko wąskim wycinkiem całego procesu kształtowania obrazu Słowiańszczyzny 
w XVIII-wiecznej Europie. Po pierwsze, Herder nie był odkrywcą słowiańskiej Europy, gdyż w swoich rozważaniach naśladował całą plejadę innych myślicieli francuskich i brytyjskich. Po drugie, Wolff celowo zmienia orientalizm w „wynalezienie Europy Wschodniej", modyfikując pierwotną koncepcję Saida. Europa Wschodnia nie miała stać się Orientem Plus, gdyż mógł on być tylko jeden, fascynujący w swej kulturowo-religijnej odmienności i zdefiniowany przez handlowo-militarne interesy mocarstw. Zamiast tego miała ona osiągnąć dyskursywny status świata pomiędzy cywilizacją i barbarzyństwem. Takiego, który opuścił już stan przedpaństwowej organizacji plemienno-terytorialnej, lecz jednocześnie nie wspiął się jeszcze na wyżyny oświecenia ówczesnej Europy zachodniej. Innymi słowy, XVIII-wieczni dyplomaci, podróżnicy, żołnierze, filozofowie i geografowie (w tej kolejności) wymyślali Europę Wschodnią na obraz i niepodobieństwo do Zachodu. Wolff zauważył:

Eastern Europe was located not at the antipode of civilisation, not dawn in the depths of barbarism, but rather on the developmental scale that measured the distance between civilisation and barbarism. [...] Eastern Europe was essentially in between, and by the nineteenth century these polar oppositions acquired the force of fixed formulas.

Zanim Herder zajął się Słowianami, powstały dziesiątki dzieł, które Europę Wschodnią opisały, scharakteryzowały, zmierzyły i policzyły (rola francuskich i włoskich geografów!), a także zaplanowały dla niej określone role polityczno-cywilizacyjne. Ten właśnie problem pojawia się podczas lektury artykułów Mikołaja Sokołowskiego i Kornelii Ćwiklak. W tych akurat tekstach prezentowane są w pewnym sensie - kontynuacje rozważań Wolffa.

Problem trzeci dotyczy roli literatury w społeczeństwach kolonialnych i postkolonialnych. Czy w przypadku piśmiennictwa polskiego lub, szerzej rzecz ujmując, literatur środkowoeuropejskich pojawił się problem ich centralnej roli w procesie podporządkowywania zależnych narodów? Czy o literaturze niemieckiej i rosyjskiej można mówić w podobny sposób, co autorzy klasycznego już tomu The Empire Writes Back o roli literatury angielskiej w Imperium Brytyjskim? Zapewne nie. Można by jednak przeanalizować poglądy czołowych postaci polskiego (i zapewne także innych) romantyzmów na rolę i znaczenie języka niemieckiego i rosyjskiego oraz wpływ obu literatur na kulturę. Dla Adama Mickiewicza, Zygmunta Krasińskiego, Maurycego Mochnackiego i Kazimierza Brodzińskiego nadmierny wpływ literatur państw, które przyczyniły się do rozbiorów, był przedmiotem troski i obawy przy jednoczesnej fascynacji ich złożonością i odkrywczością. Byłby to temat warty podjęcia.

To oczywiste, że zawsze pojawia się katalog rzeczy, które można było pomyśleć lub zaplanować inaczej. Książki pionierskie są na to szczególnie narażone. Ale odkładając na bok kwestie polemiczne, należy docenić wagę monografii, która niewątpliwie zostanie zauważona przez czytelników i już przecież zaczęła 
krążyć w bibliograficznym obiegu polskiej humanistyki. Po pierwsze, Romantyzm środkowoeuropejski w odmienny sposób problematyzuje kwestię XX- i XXI-wiecznej recepcji romantyzmu. Jawi się on dzięki tej książce nie tyle jako „piekło i niebo środkowoeuropejczyków", lecz raczej jako pewien horyzont poznawczy i (wciąż) niedokończony projekt. Romantyzm jest tak naprawdę w tej książce oświeceniem Europy Środkowowschodniej, spóźnionym nadejściem nowoczesności i jej (bolesną) modernizacją. Po drugie, książka usiłuje inaczej przedstawić kwestię intertekstualnych związków z kulturami i dyskursami dominującymi oraz inaczej rozłożyć akcenty $w$ analizie rozmaitych transferów kulturowych. Po trzecie, jest to wysokich lotów komparatystyka dzięki rosyjskim, czeskim, słowackim, ukraińskim i węgierskim kontekstom.

Książka została podzielona na dwie części. Na pierwszą składają się artykuły, na drugą zaś antologia tekstów. Obie są równie ważne i znakomicie się uzupełniają. Szczególną uwagę należy zwrócić na antologię, która znakomicie sprawdza się jako historycznoliteracka pomoc dydaktyczna dla studentów. Zawiera wiele tekstów niedostępnych wcześniej w języku polskim, czytane łącznie układają się one w fascynującą opowieść o środkowoeuropejskich zmaganiach z tożsamością. Opracowania naukowe układają się w kilka grup tematycznych: metodologia badań postkolonialnych z polskiej i środkowoeuropejskiej perspektywy (Kuziak, Skórczewski, Kola); konteksty europejskie (Sokołowski, Ćwiklak); postkolonializm i romantyzm w Polsce (Kasperski, Kożuchowski, Zawadzka, Czernik, Ławski, Gall, Kuziak, Bagłajewski, Ziemba, Rzepczyński); romantyzmy rosyjski, czeski, słowacki, węgierski, ukraiński w perspektywie postkolonialnej (Nieukerken, Pavlenko, Kola, Sosnowska, Káša, Piotrowiak-Junkiert).

Trzy wstępne teksty wytyczają kierunki lektury i interpretacji. Kuziak pisze:

Język krytyki postkolonialnej wprawdzie pojawił się w Polsce - ostatnio z coraz większą mocą, niemniej nie został dotychczas wyzyskany w pełni, zwłaszcza w odniesieniu do literatury XIX wieku. Badacze posługujący się tym językiem zajmowali się głównie XX stuleciem. Narzędzia krytyki postkolonialnej pozwalają ująć romantyzm środkowoeuropejski (romantyzmy środkowoeuropejskie) jako formację, dla której konstytutywne jest zjawisko obcej dominacji politycznej oraz kulturowej i, co zwłaszcza interesujące, pozwalają zerwać z jego jednowymiarowym rozumieniem (Kuziak 22-23).

Teksty wstępne zapraszają do dalszego snucia refleksji zapoczątkowanej przez Autorów. Szczególnie artykuł Dariusza Skórczewskiego budzi potrzebę pewnej dyskusji. Wśród wielu bardzo celnych uwag o samoorientalizacji lubelski badacz formułuje pewną ogólną opinię o imperialnej, naukowej geografii:

Trwająca od dziesięcioleci dysproporcja między udziałem uczonych z krajów byłego bloku wschodniego i ich zachodnioeuropejskich kolegów w wytwarzaniu wiedzy 
w zakresie różnych dziedzin humanistycznych to $\mathrm{m}$. in. efekt reguł gry, ustalonych i podtrzymywanych przez tę właśnie geografię, rozumianą jako naukowo utwierdzony i podtrzymywany przez wyprowadzane z niego metodologie, imperialny podział świata (Skórczewski 30).

Ta refleksja wiąże się z przekonaniem o znikomej wiedzy w anglo-amerykańskim świecie o polskiej literaturze i kulturze, zwłaszcza o naszej klasyce. Myślę, że obie te kwestie w nierozerwalny sposób przynależą do tego samego wątku rozważań i niekoniecznie są to kwestie dotyczące postkolonialnego statusu Europy Środkowowschodniej. Opinia Skórczewskiego brzmi bowiem dość dwuznacznie w świecie polskiej humanistyki, gdzie publikowanie w językach konferencyjnych i współpraca międzynarodowa wciąż uchodzą za niegroźne hobby praktykowane przez nielicznych zapaleńców. Byłbym ostrożny w zrzucaniu winy na innych, w strukturalny i odgórny sposób postponujących naszą rodzimą kulturę, tych, którzy nie znają polskiej klasyki i nie śledzą polskich badań literaturoznawczych, skoro na przykład Mickiewicz nie doczekał się współczesnych porządnych angielskich i niemieckich tłumaczeń (jest ich raptem kilka), a przekłady ważnych dzieł z zakresu polskiej humanistyki zaczęły się pojawiać na dużą skalę raptem dekadę temu. A i zachodni koledzy literaturoznawcy byliby wdzięczni za większy polski wkład we współprodukowanie ogólnej wiedzy o literaturze europejskiej, która niestety jednak musi być tworzona w językach konferencyjnych. Poza tym nieznajomość Mickiewicza i Słowackiego znaczy dzisiaj co innego niż pół wieku temu. Młodzi studenci z Niemiec i Włoch, przyjeżdżający do Poznania w ramach stypendium Erasmus, mają kłopot z dokładniejszym scharakteryzowaniem twórczości Johanna Wolfganga von Goethego i Francesca Petrarki, więc ich brak wiedzy o literaturze polskiej nie powinien dziwić. Po prostu przemiany kulturowe i cywilizacyjne sprawiły, że cała literatura sprzed XX wieku stała się obecnie literaturą dawną (i niej jest to proces nowy, lecz z pewnością rozciągający się na całą drugą połowę XX wieku). W świecie bez kanonów nie można mieć pretensji, że ktoś nie zna żadnych arcydzieł literatury polskiej, ponieważ kanoniczność przestała w międzyczasie być niepodważalnym argumentem.

Artykuły Sokołowskiego i Ćwiklak przynoszą zewnętrzne spojrzenie na Polskę z przełomu XVIII i XIX wieku. Sokołowski zajął się opisami Polski w popularnych przewodnikach angielskich, niemieckich, francuskich i włoskich. Z kolei Ćwiklak podjęła temat poglądów Goethego dotyczących Polski i Polaków. Oba teksty pokazują dyskursywną jednowymiarowość obrazu Polski, uzależnioną od wizji wykreowanej przez oświeceniową filozofię. Objawia się to między innymi w płynności poglądów na temat tego, czy Polska jest dawnym państwem, które utraciło swoją niezależność, czy jest jedynie określeniem geograficznym, etnicznym i religijnym. Zanim sprawa polska nie wypłynie na arenie europejskiej przy okazji powstania listopadowego, ta mgławicowość obrazu Polski - traktowanej jako przedsionek Azji 
i barbarzyństwa - łączy się także bezpośrednio z europejską, zwłaszcza francuską, fascynacją Rosją. Większość poglądów powtarzanych przez elity ówczesnej Europy o polskim bezrządzie i chaosie powstała pierwotnie na kartach pism Woltera i Denisa Diderota. W artykule Ćwiklak pojawia się pytanie, czy podróże na Śląsk potraktować jako podróże do Polski, skoro Śląsk nie był wówczas w żaden sposób, choćby nawet marginalnie, związany z tematyką polską. Z perspektywy niemieckiej trudno było zauważyć zmieszaną etnicznie i różnorodną religijnie ludność Śląska. Historycznie i politycznie był bowiem Śląsk nowym nabytkiem terytorialnym Prus odebranym w wyniku wygranej wojny z Austrią za życia samego Goethego (I, II i III wojna śląska). Autorka drobiazgowo rekonstruuje, gdzie w trakcie swojej podróży mógł się Goethe natknąć na polską ludność, ale trudno na to pytanie udzielić jednoznacznej odpowiedzi. Tym bardziej, że sam Goethe pochodzący z bogatej frankfurckiej rodziny nie czuł się przecież szczególnie emocjonalnie związany ze wschodnimi i południowymi rubieżami Świętego Cesarstwa Rzymskiego Narodu Niemieckiego.

Jedenaście artykułów poświęconych zostało szeroko rozumianemu polskiemu romantyzmowi. Część z nich dotyczy kluczowych postaci, wielkiej romantycznej czwórki. Edward Kasperski napisał o zjawisku przemieszczenia w twórczości Mickiewicza i Norwida. Jarosław Ławski poświęcił artykuł historycznym i kulturowym wzorom Konrada Wallenroda i Halbana. Tekst Jakuba Czernika dotyczy Maurycego Mochnackiego w kontekście projektu literatury romantycznej. Z kolei Sławomir Rzepczyński zajął się Norwidem. Spośród tych czterech artykuł Ławskiego cechuje się największą dozą sceptycyzmu wobec teorii postkolonialnej zastosowanej wobec polskiego romantyzmu. Ławski pisze o takim podejściu do badania twórczości Mickiewicza, w którym zmieniające się co kilkanaście lat metodologie decydują o usuwaniu całych obszarów z pola badawczego i zmuszają do dopasowywania twórczości poety do współczesnej terminologii. Uwagi Ławskiego dobrze współgrają z całą książką, zwłaszcza jej „polską” częścią, ponieważ uwidaczniają wyraźnie, że w przypadku problematyki postkolonialnej polskiego romantyzmu nie trzeba przycinać i dopasowywać do wcześniej istniejącego modelu, mówimy bowiem o zjawisku autentycznie rozpoznawalnym $\mathrm{w}$ tekstach literackich i pozaliterackich. Pytaniem pozostaje zawsze to, w jakim stopniu anglosaska terminologia może być stosowana $\mathrm{w}$ odniesieniu do naszego romantyzmu. Czy rację ma Jakub Czernik, pisząc: „Już same motywacje stojące za projektem literatury romantycznej jako literatury narodowej zbliżają Mochnackiego do zjawisk obserwowanych w okresie dekolonizacji i opisywanych przez badaczy postkolonializmu" (Czernik 389)? Naprawdę? Wszystkie przykłady zaczerpnięte z Mochnackiego i komentowane przez Czernika mają swoje pierwowzory w niemieckich pismach Herdera, Schellinga i braci Schleglów. Czy potrzebujemy dekolonizacji, by odkryć, że romantycy, najpierw niemieccy, później także polscy, dostrzegli rolę kultury narodowej i wspólnej przeszłości w walce o tożsamość i poczucie narodowej wspólnoty? Przywołując 
słynną książkę Pascale Casanovy, należałoby powiedzieć, że to właśnie dowód na trwałość Herderowskiej rewolucji, która pozwoliła „mniejszym” literaturom, do których zaliczała się w drugiej połowie XVIII wieku także literatura niemiecka, znaleźć dla siebie miejsce na mapie kulturowej ówczesnego świata. Antyfrancuskość, dowartościowanie własnych, lokalnych tradycji i europejskiej Północy, nawet niechęć do tłumaczenia dzieł obcych - wszystkie te elementy Mochnacki zaczerpnął z pism niemieckich krytyków i filozofów. Słowa Mochnackiego o odrzuceniu obcych wzorców są przecież w zdecydowanej większości kryptocytatami z twórców niemieckich krytykujących w dokładnie taki sam sposób wzorce francuskie, tyle że dużo wcześniej od samego Mochnackiego. Przywoływanie dekolonizacji jest w tym momencie zupełnie niepotrzebne.

Z artykułów z tej części książki (choć ułożone zostały przez redaktorów inaczej) wyłania się obraz polskich romantyków toczących bój o przyszłość narodu. $\mathrm{W}$ tej walce szczególnie często polem konfliktu jest przeszłość. Z dwugłosu Kuziaka poświęconego Słowackiemu i Krasińskiemu wyłania się obraz polskiej imperialnej przeszłości, w której czają się zarówno przyczyny rozpadu państwowości, jak i nadzieje na narodziny nowej tożsamości. Jak pisze Kuziak, szczególnie godna podkreślenia jest w tym przypadku ewolucja poglądów i artystycznych kreacji Słowackiego:

Kiedy bohaterowie wczesnych utworów Słowackiego pozostają osaczeni przez śmierć będącą doświadczeniem zamykającym ich egzystencję, w utworach późnych śmierć staje się przejściem ku nowej formie istnienia, otwiera możliwość rekonstrukcji mocnej tożsamości (również, jak pisałem, trwania pamięci), dzięki złożonej przez ducha ofierze. Tożsamość ta nie jest jednak czymś oczywistym, gotowym, danym. Okazuje się pełna sprzeczności, powstaje w trakcie traumatycznych doświadczeń. Konieczne jest bowiem zniszczenie dawnej formy, by móc wypracować nową. Pamięć, jak wspomniałem, jest czymś ambiwalentnym, jest potrzebna, by mieć świadomość tego, kim się jest, ale i grozi zamknięciem na przyszłość (Kuziak 464).

I dalej:

Lektura twórczości Słowackiego w związku z kwestią pamięci o I Rzeczypospolitej pozwala sformułować wniosek, że podmiot zależny pamięta o swojej przeszłości, ale to pamięć kłopotliwa, przymuszająca do pytania o przyczyny stanu, w który popadł. Musi sobie więc radzić nie tylko z rzeczywistością rozbiorową, z samą traumą końca I Rzeczypospolitej, ale i z pamięcią o jej imperialnych dziejach, także o wpisanej w nie skazie, która doprowadziła do katastrofy. Świadomość wielkiej przeszłości narodu może budować moc podmiotu doświadczającego współcześnie opresji, ale może też pogłębiać doświadczenie upokorzenia (Kuziak 468). 
W tym kontekście przykład biografii i autokreacji epistolograficznych Krasińskiego jaki się jako przykład „fenomenologii losu skolonizowanego” (Kuziak 474). Z jednej strony jest to dla Kuziaka szczególnie dojmujący przykład autoorientalizacji, która przyczyniła się do dominującego w tonie wielu wypowiedzi Krasińskiego poczucia gorszości i niższości, wykluczenia z Europy przy jednoczesnej świadomości, że merkantylistyczna i racjonalna Europa nie widzi już powodów, by przejmować dalej sprawą Polski. Badacz pisze:

Nie bez znaczenia w związku z podjętym tu tematem jest także [...] wątek obserwowania przez poetę postępującej modernizacji w Europie. Nowoczesność stanie się bowiem już w XIX wieku fundamentalnym zagadnieniem polskiego problemu kolonialnego (post-kolonialnego) - tak w perspektywie cywilizacyjnej, ekonomicznej, jak i w związku z nowoczesną polityką, że nie wspomnę tu o sferze kulturowo-obyczajowej. Twórca ma świadomość podziału Europy na cywilizowane centra i barbarzyńskie peryferie [...]. W ujęciu Krasińskiego jest ona [Polska - M.J.] krajem natury i zarazem innej od zachodniej, duchowej, cywilizacji (Kuziak 487).

Resentyment Krasińskiego objawił się pod postacią konstruowania mitologii narodowej i przekuwania słabości w siłę. Można łatwo zauważyć, że interpretacja autokreacji Krasińskiego ukazuje pod piórem Kuziaka jeden z kluczowych XIX-wiecznych modeli, odpowiadających za formułowanie nowoczesnego polskiego patriotyzmu, z całym sztafażem tkwiących $w$ nim niebezpieczeństw i pułapek.

Ciekawy obraz prelekcji paryskich Mickiewicza wyłania się z artykułu Alfreda Galla. W jego ujęciu Mickiewicz starał się stworzyć kontrnarrację wymierzoną w dominującą filozofię niemiecką, przy czym korzystał z reinterpretacji filozofii Heglowskiej, która przyszła wraz z berlińskimi wykładami Schellinga. Pisze autor: „W takim ujęciu początku dziejów danego narodu Mickiewicz przekłada myśl Schellinga o roli objawienia na swój dyskurs, przemieniając ontoteologiczną koncepcję niemieckiego filozofa $\mathrm{w}$ projekt historiozoficzny związany z rolą dziejową Słowian" (Gall 435). W kontekście tego tekstu przydałaby się drobna korekta. Kiedy autor pisze: „Schelling zaczął swoje wykłady o filozofii objawienia jeszcze w Monachium w 1831 roku i rozwijał tę filozofię później w Berlinie na Uniwersytecie Humboldta" (Gall 431), to chodzi oczywiście o berliński Friedrich-Wilhelms-Universität, który Uniwersytetem Humboldtów stanie się dopiero po drugiej wojnie światowej.

Szczególnie warte namysłu są artykuły dotyczące zjawisk i postaci reprezentujących inne dziedziny romantycznej egzystencji i twórczości. Jerzy Borowczyk poświęcił artykuł (będący fragmentem dużo większej całości) zesłańczym losom filomatów. Przyjmując role urzędników imperium, jednocześnie zmuszeni byli oni spełniać misje $w$ jego interesie, pozostając jednak wnikliwymi obserwatorami rzeczywistości i będąc świadomymi złożonej natury własnych działań i statusu. Borowczyk zauważa: 
Czynność pisma i przebieg pojedynczych zesłańczych biografii przyczyniały się do tego, iż filomackie doświadczenie zsyłki nigdy nie przybrało postaci jednowymiarowego dyskursu kolonialnego. Perspektywa studiów postkolonialnych pozwala jednak zobaczyć skomplikowanie sytuacji, w jakiej ci członkowie podbitego narodu znaleźli się w imperium, dążącym do podporządkowania sobie możliwie najobszerniejszego terytorium i jego mieszkańców (Borowczyk 206-207).

Dwa ważne teksty, Adama Kożuchowskiego i Danuty Zawadzkiej, dotyczą historiografii ze szczególnym uwzględnieniem Joachima Lelewela. Pierwszy z nich dotyczy poglądów na zjednoczenie ziem i ludów o różnym pochodzeniu i ludności pod egidą Rzeczypospolitej. W ujęciu Lelewela był to proces łagodnego scalania dzięki unifikującej roli religii, przeciwstawiający się późniejszej rosyjskiej, imperialnej agresji. Drugi artykuł koncentruje się na Lelewelowskich metodach konceptualizacji historii najnowszej, czyli związanej z powstaniem listopadowym i jego wychowawczym znaczeniem dla losów narodu i jego międzynarodowej reputacji. Z kolei teksty Kwiryny Ziemby, Sławomira Rzepczyńskiego i Arkadiusza Bagłajewskiego pokazują, jak wiele zostało jeszcze obszarów badawczych, na których krytyka postkolonialna mogłaby przynieść znakomite plony interpretacyjne. Wincenty Pol i Michał Czajkowski są gotowymi do podjęcia tematami, a Bagłajewski i Ziemba znakomicie sprecyzowali trudności w zrozumieniu ich metod konceptualizacji doświadczeń i pamięci po I Rzeczpospolitej.

Kolejna część książki została poświęcona literaturom i kulturom środkowoeuropejskim, czego wyraz znajdziemy w artykułach Adama F. Koli, Arenta van Nieukerkena, Svetlany Pavlenko, Danuty Sosnowskiej, Kingi Piotrowiak-Junkiert i Petera Kášy. Rozpocząć wypada od uwagi banalnej, ale wcale nie tak oczywistej w świecie polskiego literaturoznawstwa polonistycznego i slawistycznego. Prac, które próbowałyby przyglądać się zjawiskom literackim z Europy Środkowowschodniej, powstaje zdecydowanie zbyt mało, stąd praca Kuziaka i Nawrockiego jawi się (zwłaszcza z perspektywy komparatystycznej) jako pozycja szczególnie cenna i odkrywcza. Namysłowi poddane zostały tutaj sytuacje kolonialne w Czechach, Słowacji, na Węgrzech i na Ukrainie. Wiodącym tematem tej części jest śledzenie wybranych losów środkowoeuropejskich intelektualistów w ich walce o kulturową i językową emancypację. Uwidoczniła się także w ten sposób charakterystyczna cecha środkowoeuropejskich losów, gdzie procesy modernizacyjne i emancypacyjne wiązały się nie tylko z konfliktem podporządkowanych narodów z hegemonem, lecz również z wzajemną rywalizacją i wrogością.

Po lekturze książki nasuwa się oczywista konstatacja, że jest to raczej początek badań nad polskim XIX wiekiem w literaturze i kulturze, oglądanych z perspektywy postkolonialnej, i że wiele poruszonych wątków skłania do kontynuowania tej naukowej refleksji. Rozwój regionalnej, środkowoeuropejskiej wersji krytyki postkolonialnej, romantycznej i modernistycznej, jest chyba tylko kwestią czasu. 


\section{BIBLIOGRAFIA}

Ashcroft Bill, Griffiths Gareth, Tiffin Helen. The Empire Writes Back: Theory and Practice in Post-Colonial Literature. 2nd edition. Routledge: London and New York, 2002.

Borowczyk, Jerzy. Rezydenci Orientu, mieszkańcy imperium. Pisma i losy filomatów na zestaniu (1824-1870). Kuziak Michał, Nawrocki Bartłomiej, red. Romantyzm środkowoeuropejski w kontekście postkolonialnym, Cz. 1. Warszawa: Wydawnictwo IBL PAN, 2017. S. 181-206.

Casanova, Pascale. Światowa republika literatury. Przeł. Elżbieta Gałuszka, Anna Turczyn. Kraków: Wydawnictwo UJ, 2017.

Czernik, Jakub. Peryferia przeciw centrum. Mochnackiego projekt literatury romantycznej w świetle postkolonializmu. Kuziak Michał, Nawrocki Bartłomiej, red. Romantyzm środkowoeuropejski w kontekście postkolonialnym, Cz. 1. Warszawa: Wydawnictwo IBL PAN, 2017. S. 377-394.

Kieniewicz, Jan. Od ekspansji do dominacji. Próba teorii kolonializmu. Warszawa: Czytelnik, 1986.

Kieniewicz, Jan. Ekspansja. Kolonializm. Cywilizacja. Warszawa: DiG, 2008.

Kuziak, Michał. Romantyzm środkowoeuropejski w kontekście postkolonialnym. Prolegomena. Kuziak Michał, Nawrocki Bartłomiej, red. Romantyzm środkowoeuropejski w kontekście postkolonialnym, Cz. 1. Warszawa: Wydawnictwo IBL PAN, 2017. S. 7-24.

Kuziak, Michał. Juliusz Słowacki i pamięć imperium. Kuziak Michał, Nawrocki Bartłomiej, red. Romantyzm środkowoeuropejski w kontekście postkolonialnym, Cz. 1. Warszawa: Wydawnictwo IBL PAN, 2017. S. 441-468.

Kuziak, Michał. Krasiński postkolonialnie. Wokót doświadczenia stabości poety. Kuziak Michał, Nawrocki Barłłomiej, red. Romantyzm środkowoeuropejski w kontekście postkolonialnym, Cz. 1. Warszawa: Wydawnictwo IBL PAN, 2017. S. 469-490

Skórczewski, Dariusz. Romantyzm, postkolonializm i epistemologia. Kuziak Michał, Nawrocki Bartłomiej, red. Romantyzm środkowoeuropejski w kontekście postkolonialnym, Cz. 1. Warszawa: Wydawnictwo IBL PAN, 2017. S. 25-46. 
